\title{
EFEKTIFITAS PENGELOLAAN FASILITAS BELAJAR DI PERPUSTAKAAN
}

\author{
JAMALUDDIN ISKANDAR \\ Fakultas Tarbiyah dan Keguruan UIN Alauddin Makassar \\ J. HM. Yasin Limpo No. 36 Makassar \\ Email: jamaluddiniskandar@yahoo.co.id
}

\begin{abstract}
The purpose of this article is to provide readers with understanding of the effectiveness of the management of library learning facilities. To produce a quality education system, not only seen in one aspect only but covering various aspects of other support such as teachers, libraries management, financial support, and information technology. In addition, Human resources, also has an important role to make learning facilities more efective use, for including competence, skills, abilities, attitudes, behavior, motivation, and commitment.
\end{abstract}

Keywords: Management, Learning, Libraryan

\section{PENDAHULUAN}

$\mathrm{K}$

ehidupan adalah suatu proses yang dinamis dan inovatif, artinya selalu mengalami perubahan dari waktu ke waktu, dari zaman ke zaman, dan dari generasi yang satu ke generasi berikutnya, begitu seterusnya. Oleh karena itu, setiap orang harus memiliki semangat untuk melakukan perubahan dalam rangka meningkatkan kesejahtraan.Kondisi kehidupan umat manusia dari yang sangat sederhana berkembang semakin hari semakin maju dan kompleks. Kini telah memasuki kehidupan modern, yaitu kehidupan yang ditandai dengan berbagai kemajuan ilmu pengetahuan, teknologi, dan perkembangan budaya. Ciriciri kehidupan manusia modern diantaranya adalah dilihat atau diukur dengan tingkatan kemampuan dan cara berpikirnya, tata cara dan daya upaya dengan ciri khas kehidupan yang rasional dengan mengunakan logika, rasio, sistem keteraturan, kalkulasi/perhitungan dan metode, serta sistem informasi (Sutarno.h. 2).

Hal yang juga tak dapat dipungkiri adalah, perkembangan didunia pendidikan.Semula pendidikan masih menggunakan pembelajaran berbasis melek huruf.Namun, kini telah berubah, sebagian besar telah menggunakan pembelajaran berbasis komputer dan riset. Bagaimanapun kemajuan pendidikan akan cepat dicapai bila didukung sistem politik, dan ekonomi yang berpihak kepada pendidikan sehingga transformasi ilmu pengetahuan dan teknologi benar-benar mempercepat dan memudahkan serta memajukan kehidupan masyarakat (suryobroto, h 15).

Fungsi pendidikan harus betul-betul diperhatikan dalam rangka mencapai tujuan pendidikan nasional sebab tujuan berfungsi sebagai pemberi arah yang jelas 
terhadap kegiatan penyelenggaraan pendidikan sehingga penyelenggaraan pendidikan harus diarahkan kepada:

1. Pendidikan diselenggarakan secara demokratis dan berkeadilan serta tidak diskriminatif dengan menjunjung tinggi hak asasi manusia, nilai keagamaan, nilai kultural, dan kemajemukan bangsa.

2. Pendidikan diselenggarakan sebagai satu kesatuan yang sistemik dengan sistem terbuka dan multimakna.

3. Pendidikan diselenggarakan sebagai suatu proses pembudayaan dan pemberdayaan peserta didik yang berlangsung sepanjang hayat.

4. Pendidikan diselenggarakan dengan memberi keteladanan, membangun kemauan, serta mengembangkan kreativitas peserta didik dalam proses maupun kegiatan pembelajaran.

5. Pendidikan diselenggarakan dengan mengembangkan budaya membaca, menulis, dan berhitung bagi segenap warga masyarakat.

6. Pendidikan diselenggarakan dengan memberdayakan semua komponen masyarakat melalui peran serta dalam penyelenggaraan dan pengendalian mutu layanan pendidikan (Suryosubroto h. 17).

Aspek penentu lainnya agar tercapai pendidikan yang maksimal adalah pengelolaan sarana dan prasarana sekolah, jika berbicara masalah sarana dan prasarana maka segala yang berkaitan dengan fasilitas belajar yang ada di sekolah sebagai penunjang kenyamanan dan ketenangan peserta didik dalam proses belajar mengajar.

Jika ditinjau dari fungsi atau perannya terhadap pelaksanaan proses belajar mengajar, maka sarana pendidikan (sarana material) dibedakan menjadi 3 macam, yaitu: a) alat pelajaran, b) alat peraga, dan c) media pembelajaran.

Dengan membaca seseorang dapat memperluas wawasan dan pandangannya, dapat menambah dan membentuk sikap hidup yang baik, sebagai hiburan serta menambah ilmu pengetahuan. Adapun pepatah yang mengatakan bahwa "membaca membuka cakrawala dunia, perpustakaan adalah kuncinya". Artinya dengan membaca segala pengetahuan akan kita ketahui dan pahami, melalui perpustakaanlah sumber ilmu pengetahuan sepanjang masa disimpan dan tak akan pernah punah karena disanalah tempat sumber ilmu (buku) berada.

Sehubungan dengan latar belakang yang penulis telah paparkan di atas, maka penulis dapat merumuskan sebuah permasalahan yaitu: "Bagaimana efektifitas pengelolaan fasilitas belajar di perpustakaan"

\section{PEMBAHASAN}

\section{Pengertian Fasilitas Belajar di Perpustakaan}

Fasilitas belajar di perpustakaan adalah peralatan dan perlengkapan yang secara langsung dipergunakan dan menunjang proses pendidikan, khususnya proses belajar mengajar, seperti gedung, ruang kelas, meja, kursi, serta alat-alat 
dan media pengajaran. Fasilitas belajar di perpustakaan diharapkan tersediannya alat-alat belajar yang memadai secara kuantitatif, kualitatif dan relevan dengan kebutuhan serta dapat dimanfaatkan secara optimal untuk kepentingn proses pendidikan dan pengajaran, baik oleh guru sebagai pengajar dan murid sebagai pelajar. (Mulyasa, h. 49)

Perpustakaan dalam konteks ilmu manajemen adalah sebuah organisasi yang bergerak dalam bidang layanan. Salah satu unsur penting dalam manajemen adalah sebuah produk yang akan dijual. Produk tersebut dapat berbentuk dan juga tidak terbentuk.Produk berbentuk adalah produk yang dapat disentuh atau dilihat secara kasat mata, misalnya buku, pakaian, makanan, dan sebagainya.Sementara produk tidak berbentuk dalam ilmu manajemen adalah sebuah produk yang tidak kasat mata dan lebih mengarah kepada penyediaan sebuah jasa atau layanan (Quraisy, h.41).

Setiap sekolah apapun jenisnya dan jurusannya harus mempunyai perpustakaan sendiri, memberi kesempatan sama kepada semua orang/murid/mahasiswa untuk menggunakan buku-buku koleksinya. Namun kenyataannya belum semua sekolah mempunyai perpustakaan, sekolah yang sudah mempunyai perpustakaan belum sepenuhnya dapat memenuhi harapan tersebut. Yang disebabkan oleh berbagai kendala antara lain: (1). Lokasi perpustakaan yang kurang nyaman, jam buka yang sangat terbatas (misalnya, hanya pada saat jam istirahat sekolah), koleksi buku terbatas, fasilitas kurang memadai, dana terbatas; (2). Pengelolaan kurang profesional; (3). Guru kurang berpartisipasi dalam pemanfaat perpustakaan bagi siswa; (4). Kurangnya koordinasi antar perpustakaan (Supriyanto, h.276).

Fasilitas belajar di perpustakaan meliputi:

1. Ruangan Perpustakaan

Ruang perpustakaan merupakan salah satu faktor yang turut memperlancar pelaksanaan tugas-tugas pengelolaan perpustakaan. Tanpa ada ruangan tidak akan dapat menjalankan perpustakaan dengan berhasil. Dilihat dari segi administrasi dan organisasi, maka ruangan selalu menjadi faktor yang menentukan.Tidak mungkin tanpa ruangan bisa berjalan suatu organisasi dengan baik.Demikian juga perpustakaan sebagai suatu organisasi (Pawit h. 96).

Fungsi ruang perpustakaan sekolah secara umum adalah:

a. Tempat bagi para petugas melaksanakan kegiatan-kegiatan perpustakaan, yakni menghimpun, mengelola dan kemudian melayankannya kepada pengguna.

b. Tempat penyimpanan koleksi perpustakaan, baik yang fungsinya sebagai koleksi dasar pendukung kurikulum sekolah maupun koleksi penunjang.

c. Tempat dilaksanakan kegiatan rutin perpustakaan sekolah.

d. Tempat belajar secara bersama para siswa pada saat-saat tertentu. (Pawit $h$. 97). 
2. Lokasi ruangan

Perpustakaan sekolah harus terletak di lingkungan sekolah yang bersangkutan. Lokasi penempatan yang strategis, atau kira-kira dekat dari seluruh kelas-kelas yang ada di sekolah yang bersangkutan.

3. Penataan ruangan

Kondisi tata ruang perpustakaan sekolah cukup menentukan keberhasilan pengelolaan perpustakaan tersebut. Oleh karena itu ia harus ditata sebaik-baiknya, supaya dapat menumbuhkan rasa nyaman dan menyenangkan bagi penggunjung.

a. Tata ruang

Yang dimaksud tataruang perpustakaan sekolah adalah pengaturan ruangan dan bagian-bagian yang berada di dalamnya seperti perabotan dan peralatan perpustakaan lainnya.

Sehubungan dengan persyaratan dan harapan terciptanya suasana dan kondisi seperti itu, maka yang terpenting harus dilakukan adalah:

- Pintu masuk dan keluar yang digunakan untuk lalu lintas pengunjung perpustakaan hanya satu, yakni pintu yang masuk ke bagian peminjaman.

- Meja peminjaman perlu ditempatkan dekat pintu masuk.

- Lemati katalog ditempatkan di samping atau di depan meja peminjaman, agar dapat memudahkan petugas memberikan bantuan pengunjung yang menemui kesulitan.

- Rak-rak buku berada dipinggir, bergandengan dengan dinding sehingga pengamatan kepadanya dapat dijangkau dari meja peminjaman.

- Di sekitar rak buku, perlu disediakan meja baca, terutama diperuntukkan bagi mereka yang hanya ingin membaca dan belajar di perpustakaan.

- Ruang referens sebaiknya terpisah dengan ruang koleksi yang dipinjamkan dan sebaiknya ditempatkan dibagian belakang, sehingga para pembaca lebih tenang.

- Penempatan prabot dan perlatan perpustakaan yang lainnya disesuaikan dengan kondisi dan fungsinya masing-masing (Pawit h. 98).

b. Dekorasi, Penerangan dan Ventilasi

Selain kondisi tata ruang yang cukup menentukan keberhasilan pengelolaan perpustakaan, masalah dekorasi ruangan pun cukup penting kedudukannya.Dengan pengaturan dekorasi yang bagus, dapat menambah kesenangan dan kebetahan pengunjung perpustakaan untuk duduk belama-lama di perpustakaan.

Sekedar gambaran nilai dekoratif dari ruang perpustakaan sekolah yang baik antara lain mensyaratkan hal-hal berikut:

- Warna cat untuk ruangan tidak menyilaukan mata, namun juga tidak suram.

- Dekorasi dibuat dengan sederhana namun tetap menarik, atau mempunyai nilai estetika yang tinggi. 
- Sejumlah lukisan dinding yang bagus, penempatkan globe yang ditata indah, dan rapih di tempat yang tepat, juga bisa menambah nilai artistik ruang perpustakaan. (Pawit h, 99).

Mengenai penerangan ruangan perpustakaan sekolah jika menggunkan pencerahan cahaya matahari, sebaiknya dihindari cahaya matahari menembus secara langsung kepada koleksi perpustakaan, terutama buku, karena dalam waktu yang lama hal ini bisa merusak buku. Jika menggunakan lampu sebagai alat penerangan ruangan perpustakaan, sebaiknya tidak menggunakan cahaya lampu yang menyilaukan.

Adapun mengenai ventilasi udara, yang penting diusahakan agar ruangan tidak pengap.Lubang-lubang angin perlu dibuat dengan jumlah yang cukup sehingga udara bisa masuk secara leluasa.Melalui lubang angin ini juga perputaran oksigen di dalam ruangan perpustakaan dengan di luar bisa lebih lancar.

Perlengkapan Mebel dalam perlengkapan mebel yang dimaksud terdiri dari:

c. Rak buku

Rak buku dapat dibuat dari baja atau kayu.Sebaiknya rak itu dibuat terbuka dari belakang dan tidak berpintu. Dari praktik ternyata ukuran yang memuaskan adalah sebagai berikut:

Tinggi : $200 \mathrm{~cm}$

Lebar : $100 \mathrm{~cm}$

Dalam : $21 \mathrm{~cm}$ untuk rak buku biasa, $25 \mathrm{~cm}$ untuk rak buku referens, $30 \mathrm{~cm}$ untuk rak majalah. Papan paling bawah $10 \mathrm{~cm}$ dari lantai.

Tebal papan: $2 \frac{1}{2} \mathrm{~cm}$.

Meja peminjaman

Untuk meja peminjaman dapat digunakan setiap macam meja biasa atau meja tulis. Tinggi meja peminjaman dibuat $100 \mathrm{~cm}$, supaya dapat dipergunakan oleh peminjam sambil berdiri tegak di mukanya, jangan dibuat terlalu besar, supaya petugas yang duduk di belakangnya dengan mudah dapat memberikan buku kepada peminjam.

d. Lemari katalog berlaci

Lemari katalog terdiri dari laci-laci tempat menyimpan kartu-kartu katalog.Laci-laci harus dibuat $1 \mathrm{~cm}$ lebih besar dari ukuran kartu yang dipakai.Pada tiap muka laci diberi petunjuk yang nyata dan terang tentang isi laci.Selain itu, setiap isi laci diberi sebuah tongkat logam.Tongkat ini dimasukkan ke dalam lubang pada kartu.Dengan demikian tongkat itu dapat menahan kartu-kartu katalog. (Risna h, 28).

e. Kursi dan meja

Meja ruang yang cukup untuk empat orang pembaca berukuran $100 \times 150$ cm. jika dikehendaki meja bundar, maka garis tengahnya hendaklah $120 \mathrm{~cm}$ dan tingginya $75 \mathrm{~cm}$. Kursi dengan tinggi $45 \mathrm{~cm}$ sudah memenuhi syarat. Jika di bawah tiap-tiap kakinya dipasang karet, maka akan tercegahlah bunyi penyeretan kursi 


\section{Minat Baca}

Mengapa minat baca di indonesia dikatakan rendah? Ada banyak teorinya.Pertama, sistem pembelajaran di Indonesia belum membuat anakanak/siswa/mahasiswa harus membaca buku, mencari informasi/pengetahuan lebih dari yang diajarkan, mengapresiasi karya-karya sastra mislanya.Kedua, budaya baca memang belum pernah diwariskan nenek moyang kita.Kita terbiasa mendengar dan belajar berbagai dongeng, kisah, adat-istiadat secara verbal dikemukakan oleh orang tua, atau masyarakat, tidak terbiasa mencapai pengetahuan melalui bacaan.Ketiga, sarana memperoleh bacaan, seperti perpustakaan atau taman bacaan masih merupakan barang aneh dan langkah, lebih lagi jika dikaitkan dengan tingkat konsumsi masyarakat dalam membeli buku. (Supriyanto h, 272).

Dalam meningkatkan minat baca peserta didik, perpustakaan yang nyaman dan tenang serta mencirikan suatu tempat yang ramah dan menyenangkan bagi anak-anak dan remaja merupakan faktor pendukung. Untuk mencapai hal itu, langkah yang harus dilakukan adalah:

1. Menciptakan suasana membaca, dengan persyaratan: a) Fisik: ruang yang bersih, terasa lega di mana-mana buku-buku disusun secara rapih dan teratur serta terawat bersih, b) Mental: guru tidak hanya mengajar membaca, tetapi juga memotivasi anak menyukai membaca dan menjadi pembaca yang baik, c) Sarana: anak harus dikelilingi dengan buku. Oleh karena itu, sebuah perpustakaan harus mempunyai banyak koleksi yang mudah didapat.

2. Penyelenggaraan berbagai program, melalui acara yang tidak ada kaitannya secara langsung dengan buku/sastra dan melalui program sastra, yaitu berkaitan dengan bacaan.

3. Mengadakan kerja sama dengan masyarakat, orang tua, sukarelawan, penerbit, organisasi sosial, dan lain-lain.

4. Membangun jaringan kerja antarsekolah, antarperpustakaan, dan antarguru/antarpustakawan

5. Mempromosikan perpustakaan, melalui cetakan/brosur dan melalui buku telepon.

\section{Faktor-Faktor yang Mempengaruhi Minat Baca}

Minat yang dimiliki oleh setiap orang (pelajar) pastinya berbeda-beda, dengan kata lain tergantung pada masing-masing individu. Dalam hal ini, minat tersebut dengan minat terhadap membaca. Minat membaca tiap individu (siswa) tidaksama, ada pelajar yang suka dan hobi membaca dan ada pula yang tidak hobi membaca.

Namun, minat baca setiap orang (siswa) juga dipengaruhi oleh beberapa faktor, seperti yang dikemukakan oleh Crow and Crow yang dikutip dalam buku Pengantar Pengelolaan Perpustakaan Sekolah yang ditulis oleh Supriyadi, menyatakan bahwa ada empat faktor yang mempengaruhi minat baca seseorang 
(pelajar), di antaranya: a) kondisi fisik, kondisi mental, status emosi, dan lingkungan sosial. (Supriyadi h, 74).

Pertama, kondisi fisik. Kondisi fisik memang mejadi hal utama yang menjadi perhatian karena dengan kondisi fisik yang baik dan sehat, maka keadaan seseorang (siswa) akan stabil. Hal itulah yang nantinya juga akan berpengaruh terhadap aktivitas yang ia lakukan, misalnya saja kegiatan membaca buku. Apabila kondisi fisiknya sehat, maka ia akan merasa senang dan suka untuk membaca.

Kedua, kondisi mental.Tak ubahnya kondisi fisik, kondisi mental seseorang (siswa) juga sangat berpengaruh terhadap aktivitasnya sehari-hari. Apabila mental seseorang sedang down (jatuh), maka pelajar tersebut tidak akan merespon dengan baik apa yang akan ia kerjakan, misanya saja membaca buku. Sebaliknya, jika mental pelajar tersebut "bagus", maka ia akan merasa senang dan suka untuk melakukan kegiatan membaca.

Ketiga, status emosi.Tak ubahnya kondisi fisik dan mental, status emosi juga sangat berpengaruh terhadap kondisi tiap individu (siswa). Apabila kondisi emosinya stabil dan baik, maka ia kana senang dan ringan dalam melakukan kegaitan yang ia sukai, misalnya kegiatan membaca buku. Namun, apabila emosinya sedang labil, maka seorang pelajar tersebut juga enggan bahkan tidak mau untuk melakukan kegiatan apapun, tak terkecuali kegiatan membaca.

Keempat, lingkungan sosial.Lingkungan sosial setiap individu (siswa) pastinya berbeda-beda. Jika lingkungan sosial tempat individu (siswa) tinggal adalah lingkungan yang baik, dalam artian lingkungan masyarakat yang suka membaca, maka si pelajar tersebut secara tidak langsung pun akan mulai suka dengan membaca, padahal ia sebenarnya tidak hobi membaca. Namun, apabila lingkungan tempat tinggal si pelajar tidak "sehat", dalam artian kondisi masyarakat yang "amburadul", maka ia pun juga akan terpengaruh menjadi "amburadul" dan cenderung atau tidak mau melakukan kegiatan yang bermanfaat, seperti kegiatan membaca.

Dari keempat faktor yang sudah disebutkan di atas, sekiranya dapat disimpulkan bahwa kondisi fisik, mental, emosi, dan lingkungan sosial sangat berpengaruh terhadap setiap individu (siswa). Dengan kondisi fisik, mental, emosi, dan lingkungan sosial yang baik dan sehat, maka setiap individu (siswa) akan merasa senang melakukan kegiatan-kegiatan yang bermanfaat dan juga menambah wawasan pengetahuannya, seperti kegiatan membaca dan dari sinilah minta baca seseorang (siswa) akan "tumbuh.

\section{Efektifitas Pengelolaan Fasilitas Belajar di Perpustakaan}

Pendidikan yang memberdayakan adalah proses memanusiakan anak manusia sehingga potensinya menjadi aktual dalam kematangan dan kemandirian hidupnya. Hanya dengan pendidikan yang baik, setiap orang akan mengetahui hak dan tanggung jawabnya sebagai individu, anggota masyarakat, dan sebagai 
mahkluk Tuhan. Tegasnya, pendidikan merupakan hak setiap pribadi yang memungkinkan dirinya akan menjadi manusia berkepribadian paripurna. Pada gilirannya, pendidikan adalah kunci pembangunan berkelanjutan, perdamaian, dan stabilitas pada berbagai Negara.

Fungsi pendidikan harus betul-betul diperhatikan dalam rangka mencapai tujuan pendidikan nasional sebab tujuan berfungsi sebagai pemberi arah yang jelas terhadap kegiatan penyelenggaraan pendidikan sehingga penyelenggaraan pendidikan harus diarahkan kepada:

1. Pendidikan diselenggarakan secara demokratis dan berkeadilan serta tidak diskriminatif dengan menjunjung tinggi hak asasi manusia, nilai keagamaan, nilai kultural, dan kemajemukan bangsa.

2. Pendidikan diselenggarakan sebagai satu kesatuan yang sistemik dengan sistem terbuka dan multimakna.

3. Pendidikan diselenggarakan sebagai suatu proses pembudayaan dan pemberdayaan peserta didik yang berlangsung sepanjang hayat.

4. Pendidikan diselenggarakan dengan memberi keteladanan, membangun kemauan, serta mengembangkan kreativitas peserta didik dalam proses maupun kegiatan pembelajaran.

5. Pendidikan diselenggarakan dengan mengembangkan budaya membaca, menulis, dan berhitung bagi segenap warga masyarakat.

6. Pendidikan diselenggarakan dengan memberdayakan semua komponen masyarakat melalui peran serta dalam penyelenggaraan dan pengendalian mutu layanan pendidikan. (Suryosubroto h, 17).

Fasilitas belajar yang mendukung membantu meningkatkan minat baca siswa merupakan ruang lingkup dari manajemen perpustakaan, manajemen perpustakaan merupakan salah satu kajian tentang apa dan bagaimana cara-cara yang dapat dilakukan, baik melalui teori maupun praktik agar perpustakaan dapat dikelola dengan berdaya guna dan berhasil guna, sehingga keberadaannya di tengah-tengah masyarakat mampu menyeleksi, menghimpun, mengelola dan memelihara sumber informasi dan memberdayakan dengan memberikan layanan, serta nilai tambah bagi mereka yang membutuhkannya. Perpustakaan bagian keseharian sebuah kehidupan yang terus berlangsung menuju masa depan yang lebih baik, kaya pengalaman dan ilmu bukankah salah satu cara untuk menambah ilmu pengetahuan adalah dengan banyak membaca.

\section{KESIMPULAN}

Fasilitas belajar di perpustakaan adalah peralatan dan perlengkapan yang secara langsung dipergunakan dan menunjang proses pendidikan, khususnya proses belajar mengajar, seperti gedung, ruang kelas, meja, kursi, serta alat-alat dan media pengajaran. Fasilitas belajar di perpustakaan diharapkan tersediannya alat-alat belajar yang memadai secara kuantitatif, kualitatif dan relevan dengan 
kebutuhan serta dapat dimanfaatkan secara optimal untuk kepentingn proses pendidikan dan pengajaran, baik oleh guru sebagai pengajar dan murid sebagai pelajar.

\section{DAFTAR PUSTAKA}

An Nahlawi, Abdurrahman. Pendidikan Islam dirumah Sekolah dan Masyarakat, Cet. II; Jakarta: Gema Insani Press, 1996.

Arikunto, Suharsimi. Manajemen Penelitian, Cet. III; Jakarta: PT. Rineka Cipta, 1995.

Bafadal, Ibrahim. Manajemen Perlengkapan Sekolah. Cet. I; Jakarta: PT. Bumi Aksara, 2003.

Darmono. Perpustakaan Sekolah: Pendekatan Aspek Manajemen dan Tata Kerja, Cet. I; Jakarta: Grasindo, 2007.

Depertemen Agama R.I. Al-Quran dan Terjemahan, Jakarta: Jaya Sakti, 1997.

Devis, Ivor K. Pengelolaan Belajar. Cet. 1; Jakarta: CV. Rajawali, 1991.

Emzir. Metodologi Penelitian Kualitatif Analisis Data, Cet. 1; Jakarta: Rajawali Pers, 2010.

Fattah, Nanang. Landasan Manajemen Pendidikan. Cet. I; Bandung: PT. Remaja Rosdakarya, 1996.

Kamus Besar Bahasa Indonesia, Ed. III; Jakarta: Balai Pustaka, 2002.

Mathar, Muh. Quraisy. Manajemen Organisasi Perpustakaan, Cet. I; Makassar: Alauddin University Press, 2012.

Moleong, J. Lexy. Metodologi Penelitian Kualitatif, Bandung : Rosda Karya, 2002.

Mulyasa. Manajemen berbasis sekolah.Cet. I; Bandung: PT. Remaja Rosdakarya, 2002.

Narbuko, Cholid. Metodologi Penelitian, Cet 1; Jakarta: PT. Bumi Aksara, 1997.

NS, Sutarno. Manajemen Perpustakaan. Cet. II; Jakarta: CV. Sagung Seto, 2006.

Rahman, Abd., dkk, Minat Baca Murid Siswa Sekolah Dasar di Jawa Timur, Cet. I; Jakarta: Pusat Pembinaan dan Pengembangan Bahasa, 1983.

Rohani, Ahmad. Pengelolaan Pengajaran, Cet. II; Jakarta: PT. Rineka Cipta, 2004.

Sarlito, Sarwono W., Pengantar Psikoloogi Umum. Cet. I; Jakarta : PT. Rajagrafindo Persada, 2012.

Sinaga, Dian. Mengelola Perpustakaan Sekolah. Cet. 1; Bandung : Bejana, 2005. 